\title{
TRIBUTE
}

\section{A PORTRAIT OF THE ARTIST: NED ROREM AT 90}

There is much to be said for the romantic ideal, and Ned Rorem has over a lifetime said more for it than most. When I first encountered his work 35 years ago it was the nostalgia and longing of the Third Symphony (1958) which led me headlong into his art. Every piece - be it a song, a chamber work, an opera or a piano miniature starts life afresh, and maybe that is true of both his music and his words. You can start anywhere, and he makes you love the little things, the spiralling arabesques and curlicues are never the same. His epigrammatic writings and pithy mots justes have always secured him literary attention: the dozen or so sets of diaries and letters have largely remained in print over five decades and continue the traditions of Andre Gide, Max Beerbohm and G.K. Chesterton. His complete openness about his personal values and lifestyle meant that he hasn't promoted himself as a gay composer because he never needed to. I think he has relished the literary life as much as the musical and the choice of texts for the hundreds of art songs highlights a love of the American romantic poets of the nineteenth and twentieth centuries: Dickinson, Longfellow, Lowell and of course Whitman share an easy companionship with Paul Goodman, Wallace Stevens and Sylvia Plath. The American Oratorio (1984) for soloists, chorus and orchestra is an especially apt anthology but his scope is vast, ranging from James Schuyler to the Santa Fe poet Witter Bynner. Recently Thornton Wilder's play Our Town has proved a popular operatic choice, and some fifty performances have ensued over the past few years in several countries.

Rorem's early love for French culture led to a well-documented stay in France and Morocco for most of the 1950s, a time when several other American composers (David Diamond, Benjamin Lees and Nicolas Flagello, for example) escaped to a more liberal Europe from the McCarthyism of the USA. (Or was it from the sudden advent of the twelve tone-ism whose practitioners Rorem lampoons as the 'Serial Killers'?). Poulenc, Milhaud, Francaix and Ibert have continued as stylistic models, even as Rorem's musical language moved through more astringent phases and became more fragmented and cellular, starting with Air Music which won the 1976 Pulitzer Prize. A long series of instrumental concertos from the 1970s onwards won acclaim and most have been commercially recorded (three of the best, the quartet concerto Assembly and Fall (1975), the piano and cello concerto written in memory of the conductor Tommy Schippers (1979) and the 1985 Organ Concerto haven't been as yet).

His latest, Mallet Concerto (2003), follows the well-established pattern of an extended mood suite. The deeply elegiac opening mainly features the vibraphone, and the glockenspiel takes a solo in the scurrying second movement. Rorem's favoured technique of using the orchestra sparingly highlights textural clarity, in much the same way as the earliest pieces from the 1940s and 1950s, such as the first two symphonies. Despite the work's retrospective feel, Rorem's powers of invention are undimmed, and his love of animation and syncopation enliven the music with excitement and dynamism. The lovely chiming motif for marimba and trumpet in the third movement of the Concerto for Mallet Instruments recalls some of his fabled chansons d'amour. And it is followed by a waltz ... imagine yourself in a Parisian street café one sultry evening surrounded by street musicians and you will get the picture. The final part of this engaging ensemble of sketches is another elegy with vibraphone but this time there is no mistaking the nocturnal sense of closure: a distinct 'au revoir' if not 'adieu'. Rorem the miniaturist is on top form.

Naxos ${ }^{1}$ have released an album of 27 piano pieces composed over more than 25 years up to 2001 . These are thumbnail sketches averaging 1-2 minutes each and mostly dedicated to Rorem's partner of over 30 years, the organist and composer James Holmes, who died in 1999. Even tinier are a lovely set of preludes from 2007 entitled Six Friends, similar to a set of piano pieces, A Quiet Afternoon, he had written for his sister Rosemary's children almost half a

\footnotetext{
1 Ned Rorem: 'Piano Album 1; Six Friends'. Carolyn Enger (pno). Naxos American Classics 8.559761
} 
century earlier. Many of these contain the seeds of the larger works that appeared over this period, and they nicely parallel Rorem's most recent set of writings, Facing the Night (2006), a collection of diaries and short essays that include a candid appraisal of the depths of despair he endured in the aftermath of Holmes's death. The piquant turn of phrase never deserts Rorem; page after page is loaded with memorable quotations and syntactical exposés: 'He was a swell cook ... even with his strong death wish' (on David Diamond) (p. 191); 'My five identities: Atheist, Pacifist, Alcoholic (recovered), Homosexual, Composer. The first two are acquired convictions, the next two are birthright characteristics. The "Composer" is the only problem: in our society he/she is invisible' (on himself) (pp. 78); "A mind is a terrible thing to waste". A mind is not a terrible thing ... the slogan should be: "It is a terrible thing to waste a mind"' (p. 8).

In his ninetieth year Rorem has been fêted in a series of concerts. In Amsterdam, How Like a Winter, a setting of three Shakespeare sonnets for mezzo-soprano and orchestra was premiered the day before his birthday (22 October 2013), and a vast song cycle, Evidence of Things Not Seen, from 1997, was heard at the Curtis Institute in Philadelphia and also in London. The New York Festival of Song ran a series of three concerts. In 2012 his opera Our Town (libretto by J.D. (Sandy) McClatchy), based on the 1938 play by Thornton Wilder, came to London for a production at the Guildhall School of Music. First heard in a student production at the Musical Arts Center in Bloomington Indiana, in 2006, the opera is only Rorem's second full-evening opera (the first is Miss Julie (1965), the libretto for which was by Kenward Elmslie after Strindberg's play of the same name), and has already been far more successful. Our Town is the story of two families in smalltown New Hampshire in the early years of the twentieth century. The story had recently (2003) been made into a film with the late Paul Newman as the Stage Manager. The plot centres on the marriage of two school friends, George Gibbs, school baseball captain, and Emily
Webb, the class academic star, and their parents' reminiscences of their own marriage. By fast-forwarding several years between each act, the opera, like the play, focuses on the tragic inevitability of the passage of time, and the themes of birth, marriage and death are subjected to the same directness of expression by the composer as by Wilder himself: the orchestra is small, the dialogue sparse with the Stage Manager acting as narrator, and the sets are bare and with few props. The economy of resources may well be the key to the opera's mobility, and therefore its success. It was heard at Central City Opera in Denver, Colorado in July 2013 and a further production is planned in 2014 in Oklahoma.

Rorem has always been a controversial figure, but he has used his recent position as President of the 250-member American Academy of Arts and Letters to draw attention to the sorry lot of the career composer today, whom he feels is cast aside into impecunious obscurity in the face of performer celebrity culture. He touches on this in Facing the Night, for example, in recounting the occasion when he was asked to do a review of a biography of Glenn Gould and just could not bear the hyped-up, lifeless sycophancy of the author's prose style. He returned the book unreviewed, but, as always, he favoured honesty over diplomacy when explaining his reasons to the publisher. (Facing the Night, pp. 120-23). Rorem has not himself yet been the subject of a biography: I suppose most writers would feel, probably with good reason, that there is little they can say about him that he hasn't already said himself. Of his musical legacy, however, much remains to be said, because this great survivor has used his formidable intellect and talent greatly to enrich his country's culture. Nothing can detract from the enduring monuments with which he has so far endowed us, of which songs such as The Lordly Hudson and the introit Sing My Soul, His Wondrous Love, tiny though they are, are the perfect encapsulations of his art.

Bret Johnson 